\title{
Turkic Borrowings in the Turkish Language Reform: Past and Today*
}

\author{
Şükrü Halûk Akalın** \\ Mustafa Samet Kumanli ${ }^{* * *}$
}

\begin{abstract}
The purpose of this article is to investigate the practice of replacing borrowings with words from Turkic dialects during the Language Reform initiated by Ataturk. The aim of the Ataturk's Language Reform was explained as revealing the beauty of the Turkish language and achieving its significance among the world languages. To realize this aim, it was planned to eliminate Arabic and Persian words, which were seen as foreign elements, from the language and to adopt and popularize Turkish words instead. In this study, Turkic words were suggested to be used instead of foreign words during the period of language reform, and events that occurred after the language reform were discussed. Recent research conducted in the Turkish Language Society is also mentioned. As a result, a proposal was put forward to develop a common language of communication in the Turkic world.
\end{abstract}

\section{Keywords}

Language Reform, Turkey Turkish, Turkic dialects, Turkish Language Society, borrowings.

\footnotetext{
Date of Arrival: 04 September 2020 - Date of Acceptance: 16 April 2021

You can refer to this article as follows:

Akalın, Şükrü Halûk, and Mustafa Samet Kumanlı. "Turkic Borrowings in the Turkish Language Reform: Past and Today." bilig, no. 98, 2021, pp. 165-180.

" Prof. Dr., Hacettepe University, Lexicography Research and Application Center - Ankara/Turkey ORCID: 0000-0002-5313-1763 sukruhaluk.akalin@hacettepe.edu.tr

${ }^{*}$ R. Asist. Dr., Hacettepe University, Department of Turkish Language and Literature - Ankara/Turkey ORCID: 0000-0001-8262-8384 samet.kumanli@hacettepe.edu.tr
} 


\section{Introduction}

A new era started in the history of Turkish with the establishment of the Turkish Language Society (TLS) on July 12 ${ }^{\text {th }}, 1932$ with the instruction of Atatürk and the convention of the First Turkish Language Congress on September $26^{\text {th }}, 1932$. Starting four years ago with the writing system being changed from the Arabic alphabet to the new Turkish alphabet originating from Latin on November $1^{\text {st }}, 1928$ and continuing with these language breakthroughs in 1932, this period was called Atatürk's language reform. The aim of the language reform was explained as revealing the beauty of the Turkish language and attaining its value among the world languages. To realize this aim, it was planned to eliminate Arabic and Persian words, which were seen as foreign elements, from the language and to adopt and popularize Turkish words instead. Arabic and Persian words used artificially in the literary language would be removed from the language. Thus, the differences between the literary language and the language of speech would be eliminated. During this reform, which was also defined as the Turkish language, it was an important problem to find Turkish words that would be an alternative to foreign words. In general, the language revolution takes a regular and systematic form in every society, with the nationalization period and the acquisition of national consciousness. The national awakening also played a role in the Hungarian Language Revolution, which took place from the end of the 18th century to the middle of the 19th century. After the wars of 1813-15 and 1870-71 in Germany, language purification process was accelerated. After Norway achieving independence from Denmark (1814), a new movement for language independency emerged. Turkey too undertook a radical language revolution after the war of independence (İmer 32).

\section{Sources of the Pure Turkish}

Methods used during language revolutions are derivation, combining, copying meaning, reusing old elements, taking words from dialects, adapting foreign words to the phonetic system of the language, making use of different dialects, creating new words from independent roots (İmer 33-34). In parallel with these methods in the Turkish Language bulletin, the first issue of which was published in 1933 by TLS, the source of these words was listed as follows: 
a) from the Turkish folk language and folk literature, b) to revive the old western Turkish words that have fallen out of use, c) to revive the words in other historical Turkic dialects, d) to get the words from Turkic dialects which are spoken outside of the borders of Turkey. If appropriate words are not found in these sources, new words would be made using Turkish suffixes or derive compound words with these roots, firstly from Turkey Turkish word roots, if not, from Turkic dialect roots. (TDTC 14-15)

The sources of the words to be taken into the Turkish Dictionary published by the TLS were counted as follows:

All Turkish words used in spoken and literary language in the old or new Turkish dictionaries will be included in the dictionary. Those from foreign languages, that are understood by the public and that are entered into Turkish will also be included in the dictionary. If Turkish words are found to be the exact equivalent of these words, they will also be included in the dictionary. The third source is the compilation of words from the folk language. The first geographic region of the compilation was is inside the borders of Turkey. However, according to the Turkish Language Society Dictionary and Terminology Regulation Article 10/C, it is clearly stated that the wider geographical compilation area is the entire Turkic World. This issue is expressed exactly as follows in said article: "The wider geographical compilation area is the historical and geographical whole Turkic world. Turkic dialects outside our borders will be used to express concepts that do not correspond in today's Turkish spoken and literary language. In such cases, the most appropriate word for our dialect will be taken from these words and if necessary, these words will be adapted to our dialect. (TDTC 10-11)

There were strong supporters and advocates of this idea. According to Fuat Köseraif, who was called as a liquidator of language during the Ottoman Empire, all foreign language rules and foreign words, including Arabic and Persian in Turkish, had to be laid. The gap left by these foreign words should have been provided with words to be taken from Turkic dialects such as Chagatai, Azerbaijani, Kirghiz and Tatar (Sadoğlu 122). The idea of Tatar descent Sadri Maksudi was that the language reform in Turkey must be aimed "to confederate Turkic dialects" (Sadoğlu 234). 
For every foreign word listed in newspapers starting from March 1933, readers were asked to report the Turkish origin words they used in their homes and own villages. On the other hand, Turkish Language Society experts gathered forgotten Turkish words from old manuscripts. The same experts include Yakut, Kirghiz, Tatar, etc. for Turkic words that can be used instead of Arabic and Persian words. They were also researching dictionaries of Turkic dialects. "Meanwhile, local and foreign dictionaries, including Turkic dialects dictionaries and historical manuscripts are scanned, and words are revealed" (Demir 893). On the other hand, Russian bilingual dictionaries of Turkic dialects have been translated into Turkish. At the end of this translation activity, the first volume of the Yakut Dictionary, the Chuvash Dictionary, and the Kirghiz Dictionary were translated into Turkish and published by the TLS. However, about twenty dictionaries that were translated from Turkic dialects, including the works of Radloff, Verbitskiy and Budagov, have not been published. These dictionaries, which are used to select Turkic words during language reform, are stored in the "études section" of the TLS library as a memento of those days.

Essentially, the success of all these studies, just like in every language revolution, depends on popularity of the words created. In order for these words to work, care must be taken when putting them into use. A language revolution must transform the language into a cultural language. These were the main intentions of Turkish Language Revolution (İmer 53).

\section{Turkic Words, Roots and Suffixes Against the Foreign Words}

Among the words borrowed from the Turkic dialects in this period of language reform were çıray 'face' (< Tatar ubıpaŭ) instead of çehre, ertek 'fairy tale, myth' (< Kirghiz эртек(u) 'fairy tale') instead of masal, sayın 'honourable, respectable, dear' instead of mubterem, saylav 'member of parliament' (< Kazakh, Tatar сайлау 'election, election campaign' - Kirghiz шайлоо 'election) instead of mebus etc. (Bayar 248, Öztürk 304).

The new Turkish word saym "honourable, respectable, dear", which is suggested in response to the Arabic word mubterem "honourable, respectable, dear", was taken from the Turkic dialects. Eren, the author of the Etymological Dictionary of Turkish Language, gives the following information about this new word: 
Sayın is used in Turkic dialects starting from Chagatai. It is remarkable that it passes infrequently in contemporary Turkic dialects. In Kirghiz, it passes only to horses. It is not used in the Volga Kipchak dialects, but Chuvash saya 'gut' is similar to a form taken from Tatar. In Turkey Turkish, instead of the old word muhterem "honourable, respectable, dear", sayın has been suggested as a new word for the same meanings. It is understood that this proposal came from Kazan Tatars or Bashkirs who participated in the language reform. (Eren 451)

Among the suggested words to replace the borrowing kalem 'pen' from Arabic was cizgiç or sızgıç from the Karaim, or kavrı from Tatar (Lewis 50). According to Onat, "derived terim 'term' instead of the Arabic word istılah was not a corruption of the French terme but was the Kirghiz form of the word appearing in the Turkish as derim 'assembly, gathering' " (Lewis 122, Bayar 276).

Not only words, also word roots in Turkey Turkish unused or used in different ways are used to derive new words as borrowings from the Turkic dialects: Verbs such as ayt-, ayıt-derived from the root of ay-meaning "to say, to tell" in Old Turkic, from the beginning of the $14^{\text {th }}$ century, and with the effect of the thinner/y/ consonant, had changed to forms of eyt-, eyit- in Western Turkish. They were also used at the beginning period of the Ottoman Turkish, and then, because of losing their frequency, eyit- and eyt- were lost in the vocabulary of Turkey Turkish literary language. During the language reform, when the Turkish equivalent of borrowings hitabet 'oratory' and mantık 'logic' from Arabic was sought, the ayt-root used in historical and contemporary Turkic dialects was used. Aytam was suggested for the word hitabet 'oratory', which was considered obsolete, and the new word aytık for mantık 'logic' was suggested (TDK Türk Dili 117). Oydam is derived from the root $o y(<o y+d a-m)$, which means 'idea; vote' in Kipchak dialects. It has been offered as a new word instead of the Arabic origin word telkin 'suggestion' (TDK Türk Dili 128). The word oy, which is documented to be used once in the Old Anatolian Turkish period (TDK Tarama Sözlüğ̈̈ 3035), is widely used in the Kipchak group Turkic dialects. During the Language Reform, the word $o y$ was offered as a counterpart to Arabic origin word rey 'vote' and became widespread. However, oydam 'suggestion', which was proposed instead of the telkin, did not become widespread in Turkish. 
Another grammatical unit borrowed from Turkic dialects is suffixes. The suffixes, which were not used in the historical periods of Western Turkish and in the contemporary period, were used in the derivation of new words in Turkish. One of the most discussed of these suffixes is the $-v$. The new words sinav 'exam' (Bayar 252, Öztürk 309), görev 'task'(Bayar 142), ödev 'homework' (Bayar 213, Öztürk 274), söylev 'speech' (Bayar 260, Öztürk 320), türev 'derivative' (Bayar 286), terim 'term' (Bayar 276), which were proposed instead of Arabic origin words imtihan 'exam', vazife 'task; homework', nutuk 'address', müştak 'derivative', ıstılah 'term', are some of the new words derived from this suffix.

In addition to these, the most typical examples of words made with affixes from other related languages and Turkic dialects are words such as Danıstay, Yargıtay and Sayıștay with the Mongolian -tay affix (Boeschoten 170, Bayar $83,248,315)$.

These words, roots and suffixes borrowed from Turkic dialects constituted one of the intense criticisms against the Language Reform. Banguoğlu, the former president of TLS and Minister of National Education, criticizes as follows:

Pure Turkish (!) words from ten foreign languages: saylav from Tatar = Deputy. From Tatar... Tatar is not Turkic? Yes, but that's another pair of shoes. A distant dialect. The dăg 'mountain' we have has been tav 'mountain' there. It does not matter, we take out a suffix $-e v$ from there and use it out of place: söyle-v 'speech, gör-ev 'duty', öde-v 'duty', işle-v 'function', türe-v 'derivative', sina-v 'exam', oku-v 'reading'. The examples we have given since above show that our Turkish, which has preserved its dignity throughout its history, has been drifting towards degeneration and alienation rather than identification. (Banguoğlu 80)

Lewis (95) has the same idea about this suffix:

The origins of this suffix lie far from Turkey. In Bashkir and Kazakh, the infinitive ends not in $-m e k /-m a k$ but in $-v$ (preceded by the appropriate vowel after consonant-stems), and in Kirghiz and Tatar $-u$ or $-\ddot{u}$. The respective equivalents in these languages of almak 'to take' are alıv, aluv, alu, alü, and of görmek 'to see' küriv, körüv, körü, kürü. Hence several neologisms: görev 'duty', söylev 'speech', işlev 'function', ödev 'obligation', sinav 'examination', türev 'derivative, 
by-product'. Another was saylav, Kazakh and Kazan for 'to choose', used in the early years of the reform instead of milletvekili or meb'us 'deputy'. Ödev is from ödemek 'to pay'...

On the other hand, there were Arabic origin muallim 'teacher', mektep 'school', hikâye 'story' and many new Turkish words derived instead of these Arabic and Persian borrowings: ögretmen, okul, öykü... (Bayar 216, 199, 226, Öztürk 276, 262, 286). There were also those who were against the new words of Anatolian Turkish. The argument of those opposing this aspect of the Language Reform was that derivations new words from Turkish roots instead of Arabic and Persian borrowings will break the relations between Turkic world. One of them Doğru (110), who cites the words hâkimiyet 'domination', vatan 'homeland', vilayet 'province', kaza 'county', nahiye 'township', mektep 'school', cemiyet 'society', which he selected from a magazine published in the Uyghur region in the People's Republic of China, claims that deriving new Turkish words instead of these will break the contact with the Turkic world:

When these are removed from Western and East Turkestan, Azerbaijani and Iraqi Turkic, we remain pure old Turkic, and then we cannot understand each other. In other words, if these words, which have entered Anatolian folk Turkish and are cultural ties of the Turkic world, are eradicated, neither the next generations nor the other Turks will understand the Anatolian ones.

These criticisms of those against Language Reform presented a catastrophic situation beyond contradiction. On the one hand, Language Reform was criticized for borrowing Turkic origin words, roots and suffixes from the Turkic dialects, on the other hand, it was also criticized for deriving Turkic origin words instead of Arabic and Persian borrowings used in Turkic dialects.

However, supporters of the idea of borrowing words from Turkic dialects have existed since the early twentieth century. This idea had strong supporters and advocates. Some of them were Simplifiers (Sadelestirmeciler), who favored eliminating non-Turkish elements and replacing them with native words current in speech. Some were Turkicizers (Türkçeciler), who believed that new words should be created by means of the regular Turkish suffixes and that Arabic and Persian words current in popular speech should be 
counted as Turkish. Then there were the Purifiers (Tasfiyeciler), who did not object to the Turkicizers' view on the latter point but advocated borrowing words and suffixes from other dialects. Their leader Fuat Koseraif was not averse to inventing where necessary; according to Ziya Gokalp, he favored taking suffixes over from Kirghiz, Uzbek, or Tatar, or even creating them from whole cloth (Lewis 19). Sadoğlu explains his opinion on this subject in his work as follows:

According to Fuat Köseraif, who was known as a Purifier during the Ottoman Empire period, all foreign language rules and foreign words in Turkish, including Arabic and Persian, should have been discarded at the end of a language reform. The gap left by these foreign words should be provided with words taken from Turkic dialects such as Chagatay, Azerbaijani, Kirghiz and Tatar. (122)

Also, Tatar descent Sadri Maksudi's idea of purifying the language in Turkey, must be unification the Turkic dialects (Sadoğlu 234). During the years of Turkish Language Reform, the main purpose of borrowings from Turkic dialects instead of Arabic and Persian words and deriving new words from Turkic roots was to unite in the Turkish vocabulary. Sadri Maksudi has made this fact clear.

Agâh Sırrı Levend emphasizes the necessity of using Eastern Turkic and Turkic dialects as the main source of the language revolution. He states that the words derived from dialects such as organ, kurultay and tüzük should be popularized (Levend 457-458).

Zeynep Korkmaz too emphasized that the most important criteria for creating new words is the popularity, stating that words such as bağımsız, genel, özel and çoğunluk which emerged with the language revolution, have settled in the language (Korkmaz 78).

Nevnihal Bayar states that words which are commonly used in Turkey Turkish such as Yargıtay, Danıştay, sınav, görev etc. are derived inaccurately. Her opinion is based on the absence of $-v$ and -tay suffixes in Turkey Turkish. However, during the language revolution, it was more important that these words to catch on rather than the suffixes used in word making (Boeschoten 170, Bayar 83, 248, 315). 


\section{Current Situation Today}

It is seen that some of the borrowings, roots and suffixes taken from Turkic dialects during the Language Reform after nearly eighty years have settled in the vocabulary of Turkish and become widespread. Considering today, sinav 'exam', görev 'task', ödev 'homework' etc. words are frequently used in Turkish. On the other hand, çıray 'face', çizgiç 'pen', ertek 'fairy tale', kavr 'pen', saylav 'member of parliament', sızgıç 'pen' etc., which were taken from Turkic dialects in the same period have not been used since the utopian excitement has passed. In particular, the suffix $-v$ has become a widely used suffix to derive new words. It was used as a derivation of new words such as türev 'derivative', işlev 'function', not only in the 1930s, but in later periods as well (Bayar 167, Öztürk 226).

However, in the beginning of the 1970s, Turkish faced a new problem: There were no new borrowings from Arabic or Persian, but now, words entering Turkish from Western languages, from French and especially English, drew the attention of TLS. In February 1970, TSL established a new commission. The task of the commission was to find Turkish equivalents to Western words (Sinanoğlu et al. 6). When both books prepared by the commission are examined, it is seen that new Turkish words are derived from Turkish roots with Turkish suffixes (for example, emę̧ instead of aspirator) and by combining Turkish words into a compound word (for example çevrebilim instead of ecology). It is noteworthy that almost all the words used in these derivations are selected from the Turkish literary language, dialects and historical texts of Anatolian Turkish (Sinanoğlu et al., TDK Batı Kaynakli). Because, borrowing words from Turkic dialects was not included in TLS's 1965 decision. Article 13 of the decision states that folk language, old manuscripts, and derivations will be used to enrich the language (Levend 508). In the 1960s, TLS abandoned the practice of taking words from Turkic dialects, which was a fourth way in the years when the Language Reform started. This may have scientific reasons as well as political reasons. Therefore, borrowings, roots and suffixes from Turkic dialects do not exist in the new words derived against foreign words in the 1970s and 1980s. In this period, new words such as bilgisayar 'computer' (Bayar 60), yazılım 'software', donanım 'hardware' (Bayar 99, Öztürk 155), yazıcı 'printer' (Bayar 321), tarayzcı 'scanner', which were derived from new 
words, especially in the field of informatics, became widespread with great success.

\section{New Turkic Words against Foreign Words}

TLS established a new commission in 1993 against English borrowing words, which are frequently seen in Turkish in the 1990s. President of the TLS at the time, Ahmet B. Ercilasun explains the decision of this new commission to make use of the vocabulary of Turkic dialects in word derivation:

We also make use of Turkic dialects in finding new words. The fact that the Turkic world has opened before us in recent years will of course cause mutual effects in the field of language, as in all other fields. Already, some Turkish words have been used in the Turkic world. Some of the Turkic communities use the word uçak 'plane' instead of the Russian word самолет. The word çizgi film 'cartoon' has also started to be used in Azerbaijan. If we want them to use more Turkish words instead of Russian words, we should use some of their beautiful words. For example, the word açar 'key' is a genuinely nice word used instead of anahtar in Azerbaijan (also in Anatolia). Again, in Azerbaijan, çimerlik 'beach' is used instead of plaj. Why not take advantage of this rich treasure standing next to us while looking for foreign words? (TDK Yabancı Kelimelere 9-10)

Thus, TLS returned to the practice of taking words from Turkic dialects, which was practiced in the era of Ataturk, its founder and testator.

The following information is given about the words that the commission has found in Turkic dialects to be used instead of words from Western languages, especially from English and French:

aksakal 'doyen': Instead of the word duayen 'doyen', borrowed from French in Turkish, the Turkish Language Society recommended the words kıdemli or aksakal. TLS explains that the word aksakal is taken from Turkic dialects as follows: The word aksakal is used in almost all Turkic dialects to mean 'old, senior, person consulted' (TDK Yabancı Kelimelere 28).

birinci orun 'first class', işlik orun 'business class': Borrowings from English, they are used to name ticket classes in flights, trains, etc. for first class and business class, TLS used, birinci for 'first', and işlik for 'business'. TLS did not prefer Arabic borrowings sinff'class' or mevki 'class of accommodation' words in Turkish instead of class, but used orun to derive the compound 
word. TLS explains the word orun as follows: For this term, we use the word orun which means 'place, position, position' in Turkic dialects (TDK Yabancı Kelimelere 16-42).

çalar 'nuance': The word nuance borrowing from French is used in the form of nüans in Turkish. TLS has been wanted the use of the word çalar used in Azerbaijani as instead of nuance borrowed from French (TDK Yabancı Kelimelere 91).

dalan 'lobby': Borrowing from English, the word lobi 'lobby' is used in Turkish to mean waiting room at the entrance of hotels. Its second meaning in Turkish is to lobby in favor of a state, an institution or a person. TLS accepted to use the word dalan 'hall' which is used in Kars (a city in the northeast part of Turkey) and in Azerbaijani instead of the word lobby from English (TDK Yabancı Kelimelere 76-77).

uran 'slogan': Instead of the word borrowing slogan from French, which is used to mean a short and striking propaganda word in Turkish, TLS took the word uran, which is used in Kirghiz. TLS's explanation about this word is as follows: We propose a phrase that is used exactly as a slogan in today's Kirghiz Turkic: uran (TDK Yabancı Kelimelere 130).

As a result of our research on the Turkish National Corpus (Aksan et al.), unfortunately, these words are not common in Turkish, except for the articles and works of TLS members. On the other hand, with the increase of cultural relations in the Turkic world in recent years, Turkic words have started to spread in Turkish. One of the most frequently used words of the Azerbaijani language, yax̧̧ı is used today as yahşi in Turkish to mean 'good, beautiful, very beautiful', and according to the Turkish Dictionary, yahşi is one of the words used in folk language (TDK Türkçe Sözlük 2503).

The Kirghiz word mankurt used by Kirghiz novelist Cengiz Aytmatov in his work The Day Lasts More Than a Hundred Years has also been borrowed by Turkish. The word mankurt is defined in the Turkish Dictionary as follows: "Those who move away from national identity, who become alienated from the society they live in". Not only mankurt, but also the words which are derived from this root mankurtlaşmak, mankurtlaşma, and mankurtluk are used in Turkish and these are also included in the Turkish Dictionary (TDK Türkçe Sözlük 1622). 
As a result of the development of cultural, economic, and political relations in the Turkic world, Turkish words began to be used and spread in Turkic dialects. The most interesting thing is that words criticized for being incorrectly derived during the Language Reform were accepted in Turkic dialects. One of them is the word sovereignty. One of these critics of this word was Lewis:

Cep Kilavuzu (1935) defines it as '= Hâkimiyet = Souverainete'. Eyuboglu (1988: 102) explains egemen as ege or iye 'owner, master' plus -men. Tarama Sözlüğü (1963-77) shows eye or iye as in use from the fourteenth to the sixteenth century, but Eyuboglu spoils it by citing egemen as used 'halk agzında' (in the popular language) for 'master', an assertion not borne out by Derleme Sözlüğü (1963-82). Nor does he explain how the intervocalic $g$ of egemen escaped softening to $\breve{g}$. As egemenlik is obviously derived from the Greek hègemonia (which Ziya Gökalp had long ago borrowed as hegemonya), we need spend no more time on it. (Lewis 115)

However, nowadays, the word егемендлк 'souverainete' has been widely adopted in Kazakhstan, which is several thousand kilometers away from Turkey. Not only егемендıк, but also the root of the word егемен 'sovereign' and егеменль 'having sovereign rights' are used in Kazakh today (КұлМұхаммед et al. 396). Today, the most well-known and largest newspaper in Kazakhstan also bears the name Егемен.

The Turkish word gündam 'agenda, order of the day', which was criticized for being mis-derived during the Language Reform, is also widely used in Azerbaijan today. Again, the Turkish word özel 'private' at the root of the word borrowing from Turkish özallaşdirma 'privatization', which is frequently used in Azerbaijani, was one of the words criticized during the Language Reform years. An even more interesting development is the use of the $+s A l$ suffix, which was criticized as a coinage during the Language Reform, in a new derivation in Azerbaijan. This suffix is used to derive ragamsal from the Arabic root ragam 'number, digit'. The suffix in the word, which is used instead of digital in Azerbaijan today, is also in the Azerbaijani word qumsal. However, it is clear that in this derivation, the suffix is used analogously to its Turkish counterparts. 


\section{Conclusion}

These recent developments also shed light on the linguistic studies that need to be done in the $21^{\text {st }}$ century. Today, developed languages are defined as languages that have been studied, researched, published dictionaries, put forward terms, produce new terms and concepts, and find correspondence to foreign terms and concepts. The preparation of the vocabulary of Turkic dialects and the preparation of term dictionaries should be a priority. This database must be electronically processed and made accessible online. Institutions that can carry out these studies, especially TLS, are available in the Turkic republics. There is no need for large budgets or funding for this. Today, it is possible to work through online meetings using the digitalized database. The replacements for hundreds of foreign words and terms entering our languages can be found through studies on this database. The aim should be to find common correspondence not to terms that entered our languages a few centuries ago, but to new terms that have recently been introduced. A word that would be appropriate for a foreign one may exist in Kazakh, maybe in Uzbek, or maybe in a Turkic language in Siberia. Such a database can offer us a wide variety of options. The word that can be found suitable can be taken by adapting the phonetic and morphological features of the Turkic languages. Such a joint work can be both a solution to prevent our language from being influenced by foreign languages, and a new step in establishing the common communication language of the Turkic world, which has been on our agenda for several centuries.

\section{References}

Aksan, Y. et al. "Construction of the Turkish National Corpus (TNC)." In Proceedings of the Eighth International Conference on Language Resources and Evaluation (LREC). İstanbul, http://www.lrec-conf.org/proceedings/lrec2012/ papers.html (2020.01.22)

Banguoğlu, Tahsin. "On Yabancı Dilden Öztürkçe (!) Kelimeler (5)." Yaşayan Türkçemiz 1, Tercüman Gazetesi Yay, 1981, ss. 79-80.

Bayar, Nevnihal. Açıklamalı Yeni Kelimeler Sözlüğü. Akçağ Yayınevi, 2006.

Boeschoten, Hendrik “Aspects of Language Variation.” Turkish Linguistics Today, ed. H. Boeschoten -L. Verhoeven, E. J. Brill, 1991.

Demir, Nurettin. “1923-1938 Arasında Türk Dili.” Cumburiyet Dönemi Türk Kültürü, Atatürk Dönemi. 1920-1938, Atatürk Kültür Merkezi Yayınları, 2010, ss. 871-896. 
Doğru, A. Mecit. “Dilimizden Atılan ve Doğu Türkistan'da Halen Kullanılmakta Olan Kelimeler.” Yaşayan Türkçemiz 1. Tercüman Gazetesi Yayınları, 1981, ss. $110-111$.

Eren, Hasan. Eren Türk Dilinin Etimolojik Sözlüğ̈̈ (ETDES). Haz. Şükrü Halûk Akalın, Türk Dil Kurumu Yayınları, 2020.

İmer, Kamile. Dilde Değişme ve Gelişme Açısından Türk Dil Devrimi. Türk Dil Kurumu Yayınları, 1976.

Korkmaz, Zeynep. Türk Dilinin Tarihî Akışı İcinde Atatürk ve Dil Devrimi. Ankara Üniversitesi DTCF Yayınları, 1963.

Кұл-Мұхаммед, M. et al. Казак Сөздıг. Тіл Комитет, 2013.

Levend, Agâh Sırrı. Türk Dilinde Gelişme ve Sadeleşme Evreleri. Türk Dil Kurumu Yayınları, 1960.

Lewis, Geoffrey. The Turkish Language Reform: A Catastrophic Success. Oxford University Press, 1999.

Öztürk, Ali Özgün. Dil İnkılabının Türkçenin Söz Varlığına Etkileri. Türk Dil Kurumu Yayınları, 2019.

Sadoğlu, Hüseyin. Türkiye'de Ulusçuluk ve Dil Politikaları. İstanbul Bilgi Üniversitesi Yayınları, 2003.

Sinanoğlu Samim et al. Batı Kaynaklı Sözcüklere Karşılık Bulma Denemesi I. Türk Dil Kurumu Yayınları, 1972.

TDK. Türk Dili, Türk Dil Kurumu Bülteni 17-18, 1936.

TDK. Batı Kaynaklı Sözcüklere Karşılık Bulma Denemesi I. Türk Dil Kurumu Yayınları, 1978.

TDK. Yabancı Kelimelere Karşılıklar. Türk Dil Kurumu Yayınları, 1995.

TDK. Yabancı Kelimelere Karşılıklar. Türk Dil Kurumu Yayınları, 2002.

TDK. Tarama Sözlüğ̈̈. Türk Dil Kurumu Yayınları, 2009.

TDK. Türkçe Sözlük. Türk Dil Kurumu Yayınları, 2019.

TDTC. Türk Dili, Türk Dili Tetkik Cemiyeti Bülteni 1, 1933. 


\title{
Dil Devrimi Sırasında Türk Lehçelerinden Alıntılar: Geçmiş ve Bugün*
}

\author{
Şükrü Halûk Akalın** \\ Mustafa Samet Kumanlı ${ }^{* * *}$
}

\begin{abstract}
O̊z
Bu makalenin amacı, Atatürk'ün başlattığı Dil Devrimi sırasında Türkçeyi özleştirmek düşüncesiyle dildeki ödünçlemeler yerine Türk lehçelerinden alınan kelimeleri yerleştirme uygulamasını incelemektir. Atatürk'ün Dil Devrimi'nin amacı, Türk dilinin öz güzelliğini ortaya çıkarmak ve onu dünya dilleri arasında değerine yaraşır yerine ulaştırmaktı. Bu amacı gerçekleştirmek için yabancı unsur olarak görülen Arapça ve Farsça kelimelerin dilden çıkarılması ve bunların yerine Türkçe kökenli kelimelerin benimsenmesi ve yaygınlaştırılması amaçlanmıştı. Bu çalışmada, Dil Devrimi sırasında yabancı kelimeler yerine tercih edilen dört yoldan biri olan Türk lehçelerinden kelimelerin önerilmesi uygulaması, başarı düzeyi ve sonrasında yaşanan gelişmeler tartışılmıştır. Türk Dil Kurumunda son yıllarda bu konuda yapılan çalışmalara da değinilmiştir. Sonuç olarak, Türk dünyasında ortak iletişim dilinin geliştirilmesinde bu uygulama bir öneri olarak dile getirilmiştir.
\end{abstract}

\section{Anahtar kelimeler}

Dil Devrimi, Türkiye Türkçesi, Türk lehçeleri, Türk Dil Kurumu, alıntılar.

\footnotetext{
Geliş Tarihi: 04 Eylül 2020 - Kabul Tarihi: 16 Nisan 2021

Bu makaleyi şu şekilde kaynak gösterebilirsiniz:

Akalın, Şükrü Halûk, and Mustafa Samet Kumanlı. "Turkic Borrowings in the Turkish Language Reform: Past and Today.” bilig, no. 98, 2021, pp. 165-180.

** Prof. Dr., Hacettepe Üniversitesi, Sözlük Bilimi Uygulama ve Araştırma Merkezi - Ankara/Türkiye ORCID: 0000-0002-5313-1763 sukruhaluk.akalin@hacettepe.edu.tr

${ }^{* * *}$ Araş. Gör. Dr., Hacettepe Üniversitesi, Türk Dili ve Edebiyatı Bölümü - Ankara/Türkiye ORCID: 0000-0001-8262-8384 samet.kumanli@hacettepe.edu.tr
} 


\title{
Тюркские заимствования в реформе турецкого языка: прошлое и настоящее*
}

\author{
Шюкрю Халюк Акалын ${ }^{* *}$ \\ Мустафра Самет Куманлы
}

\begin{abstract}
Аннотация
Целью данной статьи является исследование практики замены иностранных заимствований словами из тюркских диалектов в ходе языковой реформы, инициированной Ататюрком. Новый период начался в истории турецкого языка с создания по указу Ататюрка Общества турецкого языка 12 июля 1932 года и Первого конгресса турецкого языка 26 сентября 1932 года. Этот период начался четырьмя годами ранее с изменения системы письма с арабского алфавита на новый турецкий алфавит, возникший с латыни 1 ноября 1928 года и продолжившийся с этими языковыми прорывами в 1932 году, была названа языковая реформа Ататюрка. Цель языковой реформы Ататюрка была объяснена как раскрытие красоты турецкого языка и достижение его значимости среди языков мира. Для реализации этой цели планировалось исключить из языка арабские и персидские слова, которые считались иностранными элементами, и вместо этого принять и популяризировать тюркские слова. В данном исследовании предлагалось использовать тюркские слова вместо иностранных слов в период языковой реформы, и обсуждались события, произошедшие после языковой реформы. Также упоминается недавнее исследование, проведенное Обществом турецкого языка. В результате было выдвинуто предложение разработать общий язык общения в тюркском мире.
\end{abstract}

\section{Ключевые слова}

Языковая реформа,турецкий, тюркские диалекты, Общество турецкого языка, заимствования.

\footnotetext{
Поступило в редакцию: 04 сентября 2020 г. - Принято в номер: 16 апреля 2021 г. Ссылка на статью:

Akalın, Şükrü Halûk, and Mustafa Samet Kumanlı. "Turkic Borrowings in the Turkish Language Reform: Past and Today." bilig, no. 98, 2021, pp. 165-180.

** Проф., Д-р, Прикладного и научно-исследовательского центра лексикографики Университета Хаджеттепе - Анкара / Турция ORCID: 0000-0002-5313-1763 sukruhaluk.akalin@hacettepe.edu.tr

*** Научный сотрудник, д-р., Университет Хаджеттепе, Кафедра турецкого языка и литературы, Анкара / Турция ORCID: 0000-0001-8262-8384 samet.kumanli@hacettepe.edu.tr,m.sametkumanli@outlook.com
} 